\title{
Potensi Energi Arus Laut di Perairan Selat Sunda
}

\section{Nuriyati $^{1}$, Purwanto ${ }^{1}$, Heryoso Setiyono ${ }^{1}$, Warsito Atmodjo ${ }^{1}$, Petrus Subardjo ${ }^{1}$, Aris Ismanto ${ }^{1}$, Muslim $^{1}$}

\author{
${ }^{1}$ Departemen Oseanografi, Fakultas Perikanan dan Ilmu Kelautan, Universitas Diponegoro \\ J1. Prof. Sudarto, SH Tembalang Tlp. / Fax. (024)7474698 Semarang 50275 \\ Email corresponding author: nuriyati15@gmail.com
}

\begin{abstract}
Abstrak
Arus Laut merupakan salah satu sumber energi terbarukan yang potensial untuk dikembangkan mengingat banyaknya pulau dan selat yang ada di Indonesia. Selat Sunda yang berada di antara Samudera Hindia dan Laut Jawa yang dipengaruhi oleh massa air dari Samudera Pasifik menjadi salah satu lokasi potensial. Tujuan dari penelitian ini adalah untuk mengetahui karakteristik arus laut beserta potensi energi arus laut yang dihasilkan. Penelitian ini menggunakan metode kuantitatif dan penentuan lokasi dengan metode sampling area. Pengolahan data dibagi menjadi tiga tahap yaitu analisa data arus dan pasang surut, pemodelan numerik dan perhitungan estimasi rapat daya. Hasil menunjukkan bahwa kecepatan arus maksimum sebesar $1,95 \mathrm{~m} / \mathrm{s}$. Daya terbesar dihasilkan pada saat kondisi surut menuju pasang yaitu sebesar $4,51 \mathrm{~W} / \mathrm{m}^{2}$ di daerah antara Pulau Peucang dan Ujung Kulon.
\end{abstract}

Kata kunci: Arus Laut, Pemodelan, Energi Terbarukan, Selat Sunda.

Abstract

Ocean current is one of the potential renewable energy sources to be developed considering there are many islands and straits that exist in Indonesia. Sunda strait that located between Indian Ocean and Java Sea be affected water masses from Pacific Ocean to be one of potential location. The purpose of this study is to determine the characteristics of ocean currents and the potential of ocean current energy that can be generated. This study used a quantitative method and determination of the location with sampling area. Data Processing is divided into 3 major phases which is analysis for currents and tides, numerical modeling and calculation of power density estimation. The results showed that the maximum of ocean current velocity is $1.95 \mathrm{~m} / \mathrm{s}$. The biggest power density is generated during ebb to flood is $4.51 \mathrm{~W} / \mathrm{m}^{2}$ in the area between Peucang island and Ujung Kulon.

Keywords: Sea Currents, Modeling, Renewable Energy, Sunda Strait.

\section{PENDAHULUAN}

Seiring dengan semakin bertambahnya jumlah penduduk, pasokan energi untuk pembangkit listrik di Indonesia cenderung meningkat. Berdasarkan data dari PT. PLN (Persero), kebutuhan energi listrik pada tahun 2025 akan tumbuh rata-rata sebesar 8,6\% per tahun untuk periode tahun 2016-2025. Sumber energi listrik di Indonesia saat ini masih didominasi oleh energi konvensional, yakni energi fosil yang ketersediaannya terbatas di alam karena tidak dapat diperbaharui serta menimbulkan masalah lingkungan seperti polusi dan pemanasan global (KESDM, 2012).

Selat Sunda yang memisahkan Pulau Jawa dan Pulau Sumatera merupakan selat yang memiliki peranan penting dalam kehidupan sehari-hari terutama pada bidang sosial, ekonomi, dan keamanan. Berbagai aktivitas seperti pusat pemukiman, pelabuhan, dan industri terdapat di wilayah perairan Selat Transpor massa air antara Laut Jawa dengan Samudera Hindia melewati Selat Sunda mengalir ke arah yang berlawanan tergantung musimnya (Dishidros-AL, 1998 dalam Pariwono, 1999).

Perairan Selat Sunda memiliki potensi yang cukup besar untuk dimanfaatkan sebagai pembangkit listrik tenaga arus laut. Wilayah perairan selat merupakan tempat melintasnya dan berkumpulnya massa air laut. Pada lokasi selat ini memungkinkan massa air laut mengumpul dan bergerak lebih cepat karena semakin menyempitnya ruang gerak dari laut menuju selat. Pada tempat inilah yang terdapat potensi energi terbesar dari perairan sekitarnya (Moreno et al., 2008). 
Melalui pertimbangan tersebut maka diperlukan kajian lebih lanjut untuk mengetahui karakteristik arus laut dan besarnya potensi energi arus laut yang dapat digunakan sebagai energi alternatif pembangkit listrik di sekitar Perairan Selat Sunda. Peta lokasi penelitian ditunjukkan pada Gambar 1.

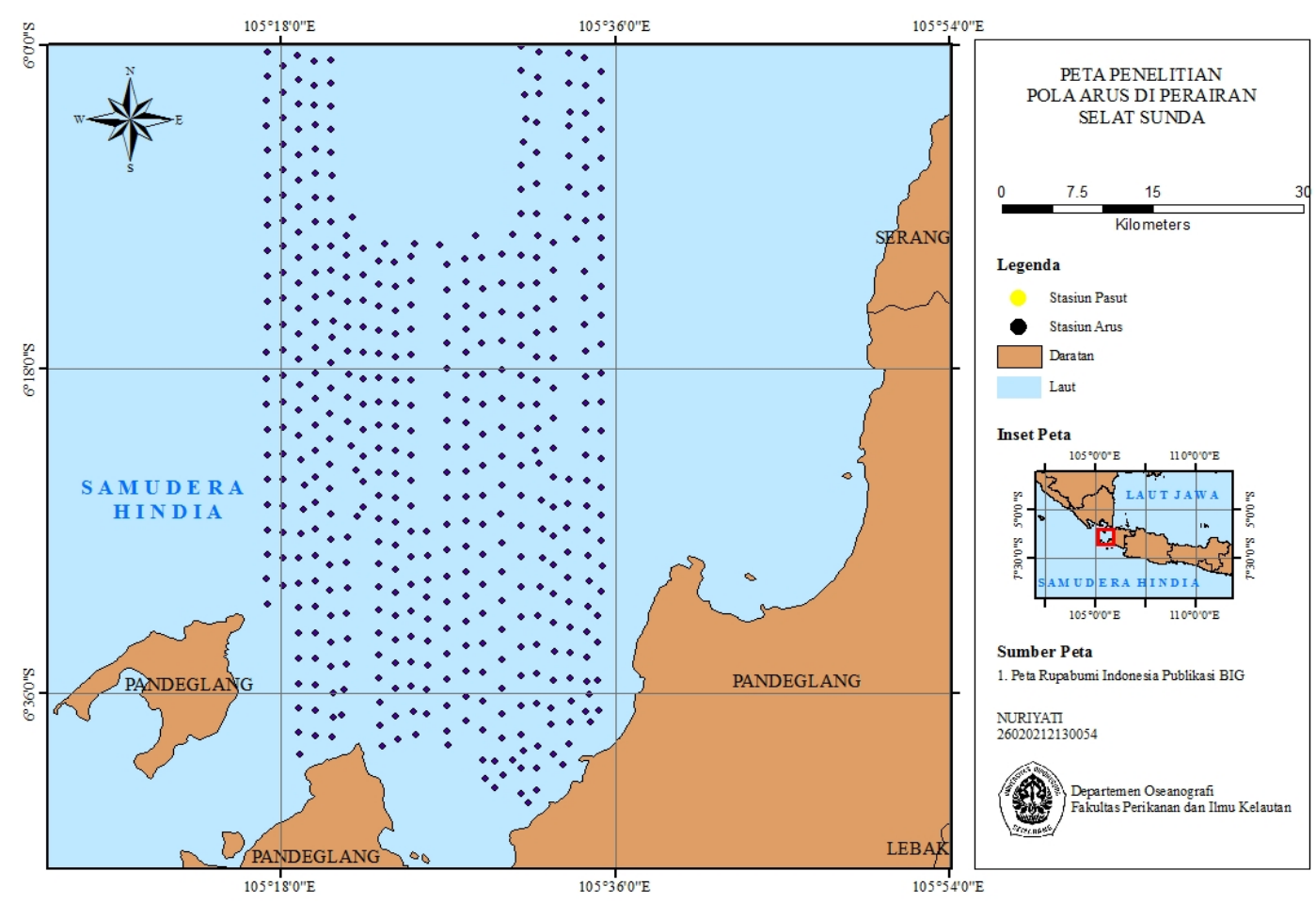

Gambar 1. Peta Lokasi Peneitian

\section{MATERI DAN METODE PENELITIAN}

Materi utama yang digunakan dalam penelitian ini adalah data arus laut. Materi penunjang yang digunakan antara lain data pasang surut pada bulan Mei 2016, peta Rupabumi Indonesia (RBI) yang dipublikasi Badan Informasi Geospasial (BIG) tahun 1999 dengan skala 1:25.000, dan peta batimetri Selat Sunda skala 1:200.000 yang dipublikasi DISHIDROS TNI-AL tahun perbaharuan 2014.

Metode penelitian yang digunakan dalam penelitian ini adalah metode kuantitatif. Metode kuantitatif adalah metode yang digunakan untuk meneliti populasi atau sampel tertentu, pengumpulan data menggunakan instrumen penelitian serta data yang sudah didapat diolah menjadi bentuk angka. Penentuan lokasi pengukuran arus laut dan pasang surut dengan menggunakan sampling area. Jika luasan daerah sampling sangat luas, maka penggunaan metode area sampling (sampling area) dapat dilakukan, karena hanya mengambil beberapa titik yang mewakili keadaan lokasi penelitian (Sugiyono, 2009).

Pengukuran arus dilakukan dengan menggunakan ADCP dengan jenis Teledyne Vessel Mounted ADCP menggunakan frekuensi $150 \mathrm{~Hz}$ yang dipasang di bawah kapal. ADCP ini mengukur tiap detik namun pada saat ekstraksi diambil setiap 10 menit pengukuran. Kemampuan alat pengukuran mencapai kedalaman maksimal $200 \mathrm{~m}$ dengan tiap-tiap layer kedalaman diukur kecepatan dan arah arus (Teledyne Technology Company, 2016).

Pengamatan elevasi muka air dalam menentukan pasang surut dilaksanakan selama 31 hari dengan interval pengamatan setiap 1 jam. Pengukuran pasut dilakukan pada koordinat 6²8'41.94"S - 105 39'29.63"E Tanjung Lesung, Banten.

Data arus yang diperoleh dari lapangan kemudian disajikan dalam bentuk current rose dan dianalisa agar mengetahui kontribusi besarnya arus pasut dan non pasut dengan menggunakan wordcurrent. Sedangkan untuk simulasi numerik arus laut menggunakan software MIKE 21 modul Flow Model FM (Flexibel Mesh).

Analisa data pasang surut menggunakan Metode Admiralty yang menghasilkan komponen pasang surut untuk mengetahui nilai MSL, HHWL, LLWL dan tipe pasang surut. Nilai rapat daya yang dihasilkan dapat dihitung dengan menggunakan persamaan Fraenkel (2001) 


$$
P=\frac{1}{2} \rho A V^{3}
$$

dimana $P$ adalah daya (Watt); $\rho$ adalah densitas air laut $(\mathrm{kg} / \mathrm{m} 3) ; A$ adalah luas penampang turbin yang digunakan $\left(\mathrm{m}^{2}\right)$; dan $V$ adalah kecepatan arus laut $(\mathrm{m} / \mathrm{s})$. Nilai densitas air laut yang digunakan adalah sama $1025 \mathrm{~kg} / \mathrm{m}^{3}$ Luas penampang turbin (A) dianggap $1 \mathrm{~m}^{2}$ sehingga variabel yang paling berpengaruh dalam proses perhitungan konversi menjadi arus listrik adalah kecepatan arus dan luas turbin (Fraenkel, 2001).

\section{HASIL DAN PEMBAHASAN}

Hasil dari penelitian ini berupa distribusi arus laut, pasang surut, simulasi pola arus dan potensi rapat daya, serta verifikasi arus laut dan pasang surut.

Hasil Pengukuran Arus Lapangan

Tabel 1. Data Kecepatan Arus di Perairan Selat Sunda

\begin{tabular}{cccc}
$\begin{array}{c}\text { Kedalaman } \\
(\mathrm{m})\end{array}$ & $\begin{array}{r}\text { Kecepatan Max } \\
(\mathrm{m} / \mathrm{s})\end{array}$ & Arah Arus Max & $\begin{array}{c}\text { Kecepatan Rata- } \\
\text { Rata }(\mathrm{m} / \mathrm{s})\end{array}$ \\
\hline 11,7 & 0,53 & Timur Laut & 0,17 \\
15,7 & 0,49 & Timur & 0,15 \\
19,7 & 0,55 & Timur Laut & 0,15 \\
23,77 & 0,51 & Barat Daya & 0,15 \\
27,78 & 1,38 & Utara & 0,17 \\
31,77 & 1,95 & Utara & 0,20 \\
35,77 & 1,76 & Utara & 0,19 \\
39,77 & 0,77 & Selatan & 0,18 \\
43,77 & 1,69 & Utara & 0,19 \\
\hline
\end{tabular}

Kecepatan maksimum tertinggi terdapat di kedalaman 31,77 m dengan nilai kecepatan 1,95 m/dt pada arah utara. Sedangkan kecepatan rata-rata tertinggi terdapat pada kedalaman 31,77 meter dengan nilai kecepatan sebesar $0,20 \mathrm{~m} / \mathrm{dt}$. Sedangkan nilai kecepatan rata-rata terendah terdapat pada kedalaman 15,7 m, $19,7 \mathrm{~m}$ dan $23,77 \mathrm{~m}$.

Hasil dari pengolahan Current rose menunjukkan bahwa arah dominan arus laut di Perairan Selat Sunda adalah ke arah selatan dan barat daya.

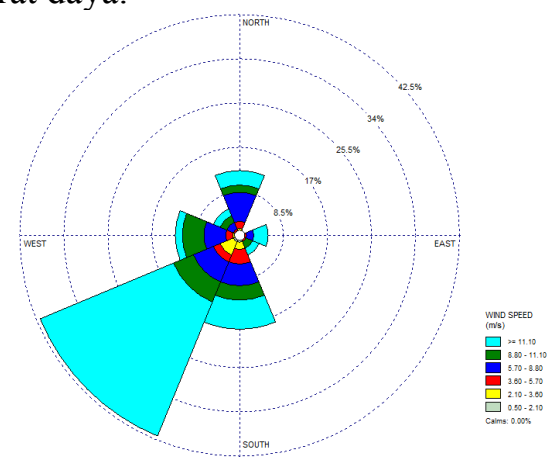

Karakteristik Arus

Gambar 2. Distribusi Arah dan Kecepatan Arus di Perairan Selat Sunda

Gambar 3 menunjukkan bahwa Perairan Selat Sunda memiliki dominansi arus laut yang dibangkitkan oleh arus residu. Hal itu dapat diketahui dari hasil pengolahan data arus yang disajikan dalam grafik World Current. Menurut Poerbandono dan Djunasjah (2005), fenomena arus pasut sangat terasa pada wilayah 
perairan tertutup (teluk), selat, perairan dangkal, kanal-kanal pasut serta muara sungai (delta dan estuari). Namun karena daerah penelitian berdekatan dengan Samudera Hindia (daerah oseanik) menyebabkan pengaruh angin lebih besar dibanding pasang surut.

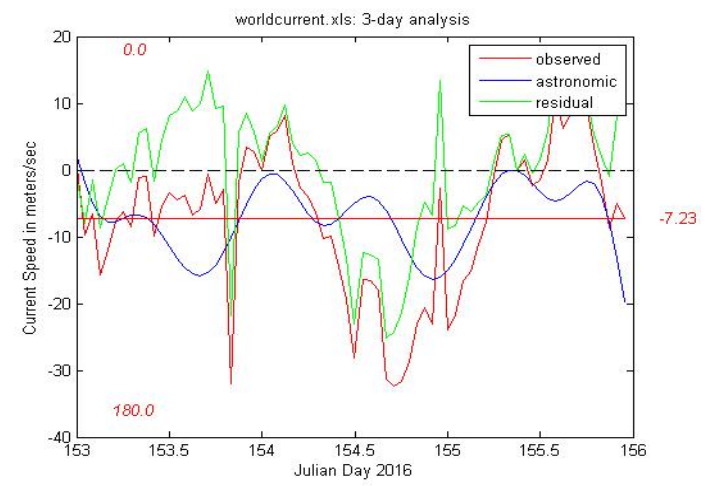

Pasang Surut

Gambar 3. Distribusi Arah dan Kecepatan Arus di Perairan Selat Sunda

Berdasarkan hasil pengolahan data pasang surut dengan Metode Admiralty, maka dapat diketahui bahwa Perairan Selat Sunda memiliki tipe pasang surut campuran condong ke harian ganda (mixed tide prevailing semidiurnal) dimana dalam satu hari terjadi dua kali air pasang dan dua kali air surut, tetapi tinggi dan periodenya berbeda. Hal itu dapat diketahui dari perhitungan nilai Formzahl, yaitu dengan membandingkan nilai amplitudo (tinggi gelombang) unsur pasang surut tunggal utama dengan amplitudo unsur pasang surut ganda utama yang menghasilkan nilai bilangan Formzahl sebesar $0,434(0,25<\mathrm{F}<1,50)$.

Hal ini sesuai dengan pernyataan Pariwono (1999), tipe pasang surut di perairan barat Lampung dan sekitar Selat Sunda adalah campuran dominasi ganda yang diperkirakan karena adanya pengaruh dari Samudera Hindia dengan tipe yang sama. Pasang surut dari Samudera Hindia merambat ke Selat Sunda hingga Laut Jawa, kemudian mengalami perubahan akibat perairan Selat Sunda dan Laut Jawa yang dangkal. Sampai di Laut Jawa tipe pasang surut menjadi campuran dominasi tunggal. Tipe pasang surut dapat berubah karena perubahan kondisi kedalaman perairan.

Tabel 2. Nilai Komponen Pasang Surut

\begin{tabular}{ccc}
\hline Komponen Pasang Surut & $\begin{array}{c}\text { Amplitudo } \\
(\mathbf{c m})\end{array}$ & Beda Fasa $\left(\mathbf{g}^{\mathbf{0}}\right)$ \\
\hline $\mathrm{S}_{\mathrm{o}}$ & 118,84 & 0 \\
$\mathrm{M}_{2}$ & 34,83 & 285,3 \\
$\mathrm{~S}_{2}$ & 14,18 & 35,51 \\
$\mathrm{~N}_{2}$ & 7,26 & 620,43 \\
$\mathrm{~K}_{1}$ & 15,22 & 29,09 \\
$\mathrm{O}_{1}$ & 9,94 & 537,20 \\
$\mathrm{M}_{4}$ & 0,52 & 218,70 \\
$\mathrm{MS}_{4}$ & 0,34 & 313,61 \\
$\mathrm{~K}_{2}$ & 3,26 & 396 \\
$\mathrm{P}_{1}$ & 5,022 & 389,09 \\
\hline
\end{tabular}




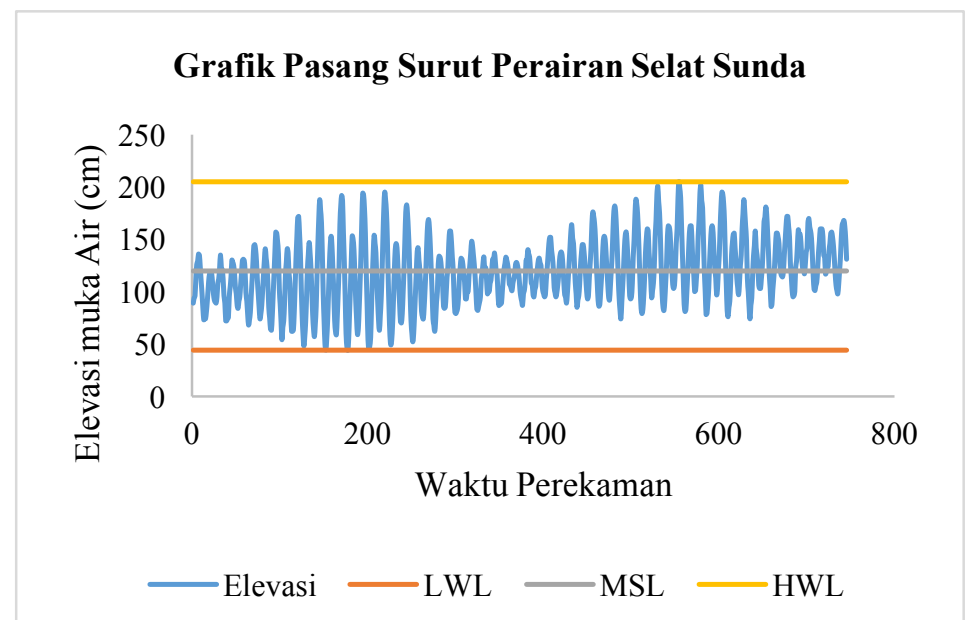

Gambar 4. Elevasi Muka Air Pasang Surut di Perairan Selat Sunda

Simulasi Pola Arus dan Potensi Rapat Daya

Peta pola arus (Gambar 4a-d) menjelaskan bagaimana pola arus yang terjadi dari hasil simulasi model dengan menggunakan software DHI MIKE 21. Pola pergerakan arus hasil simulasi model merupakan pola arus yang dibangkitkan oleh pasang surut dengan asumsi tidak ada pengaruh angin maupun gesekan dasar. (Gambar 4a) menunjukkan peta pola pergerakan arus saat pasang yang bergerak dari arah timur laut menuju barat daya (Laut Jawa menuju Samudera Hindia) dengan kecepatan rata-rata $0,025 \mathrm{~m} / \mathrm{s}$ pada lokasi pengukuran arus. Saat kondisi pasang menuju surut (Gambar 4b) arus bergerak ke arah timur laut, yaitu dari Samudera Hindia menuju Laut Jawa dengan kecepatan rata-rata $0,061 \mathrm{~m} / \mathrm{s}$. (Gambar 4c) Saat kondisi surut terendah menunjukkan pola arus yang hampir sama dengan pola arus saat pasang menuju surut, yaitu arus bergerak dari arah Samudera Hindia menuju pantai Pandeglang dan sebagian menuju Laut Jawa dengan kecepatan rata-rata pada lokasi penelitian sebesar $0,04 \mathrm{~m} / \mathrm{s}$. Sedangkan saat kondisi surut menuju pasang (Gambar 4d) menunjukkan pergerakan arus dari arah timur laut menuju barat daya, yaitu dari Laut Jawa menuju Samudera Hindia dengan kecepatan rata-rata $0,043 \mathrm{~m} / \mathrm{s}$ pada lokasi penelitian. Hal ini sesuai dengan pernyataan dari Poerbandana dan Djunarsah (2005), arus pasut memiliki sifat bergerak dengan arah yang saling bertolak belakang atau bidirectional. Arah arus saat pasang biasanya bertolak belakang dengan arah arus saat surut.

Spasial rapat daya yang menunjukkan besarnya potensi energi arus laut di Perairan Selat Sunda dapat dilihat pada (Gambar 5a-d). Gradasi warna yang dihasilkan menunjukkan rentang nilai yang dihasilkan dari konversi kecepatan arus laut. Nilai rapat daya tertinggi berada di antara pantai Ujung Kulon dan Pulau Peucang (Ma Cikuya dan Tanjung Jungkulan) yang ditandai dengan warna ungu-pink (menunjukkan nilai rapat daya tertinggi). Hal ini sesuai dengan teori dari (Hagerman, 2006) yang menyatakan bahwa, semakin luas dan dalam suatu kanal maka kecepatannya kecil. Sebaliknya, apabila semakin sempit dan dangkal suatu kanal maka kecepatannya membesar, perairan selat diasumsikan sebagai kanal. Keadaan ini diakibatkan oleh parameter oseanografi yang saling berkaitan satu sama lain, dimana kecepatan arus berbanding lurus dengan daya yang dihasilkan sesuai dengan persamaan 1, persamaan yang diberikan oleh Moreno (2008), untuk konversi kecepatan arus menjadi daya. Sedangkan untuk nilai konversi rapat daya tertinggi paling banyak terjadi pada saat kondisi pasang menuju surut dan surut menuju pasang. Hal ini sesuai dengan pernyataan dari Hadi dan Radjawane (2009), pada saat pasang menuju surut atau surut menuju pasang kecepatan arus pasut maksimum terjadi. 


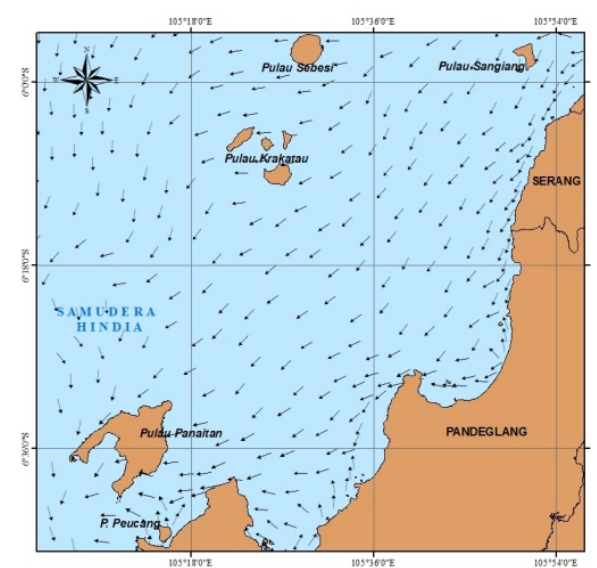

(a)

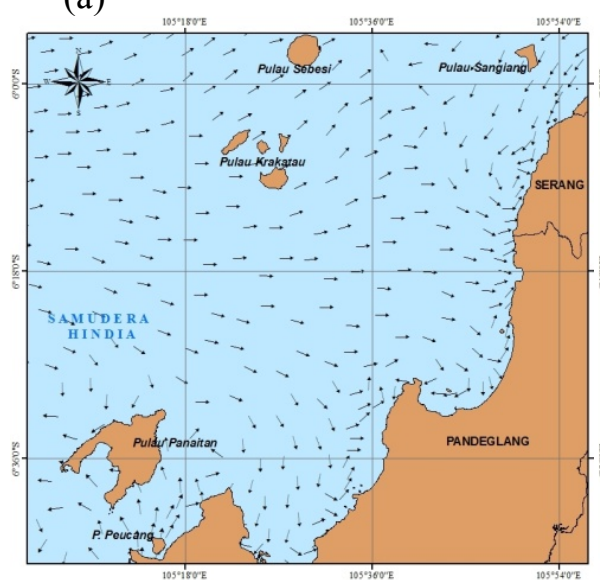

(c)

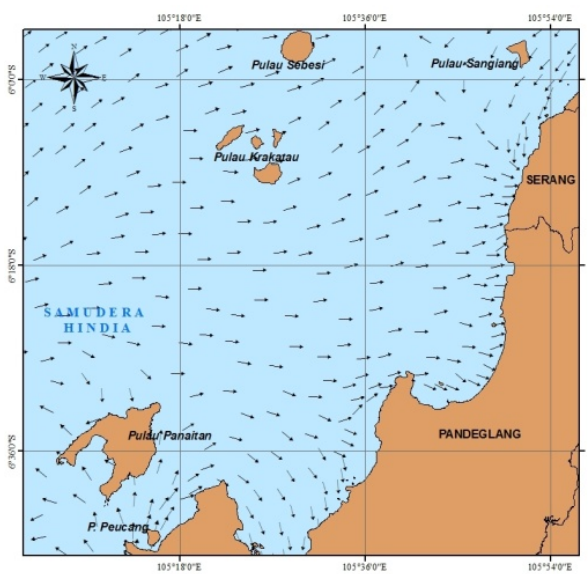

(b)

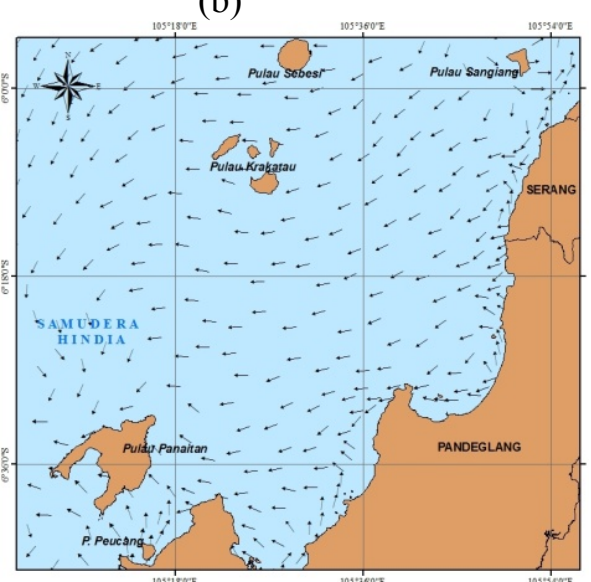

(d)

Kecep atan Arus (m/s)

$\uparrow \quad 0.001-0.07$

$\uparrow \quad 0.07-0.2$

$\uparrow \quad 0.2-0.6$

Gambar 5. Pola Arus di Perairan Selat Sunda (a. Saat Kondisi Pasang, b. Saat Pasang Menuju Surut, c. Saat Surut Terendah, d. Saat Surut Menuju Pasang)

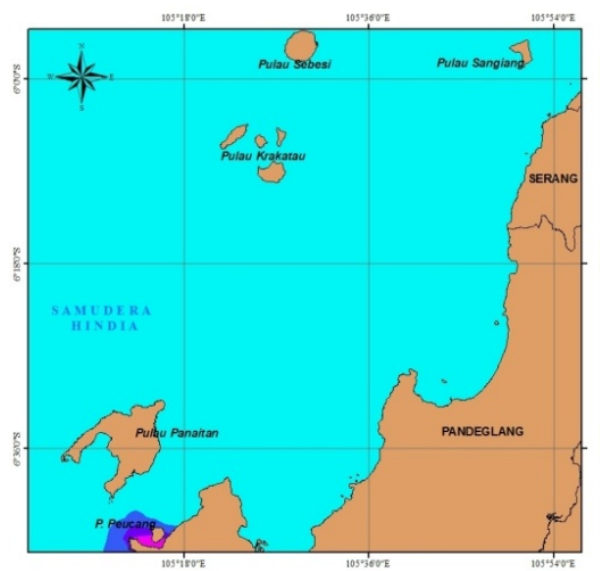

a. Saat Pasang Tertinggi

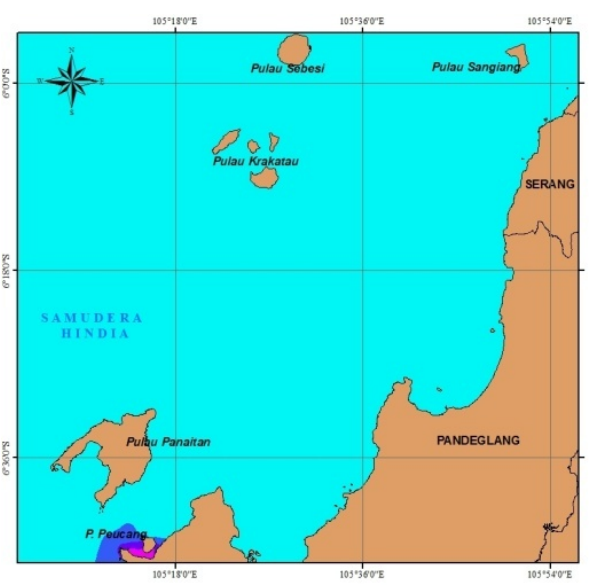

b. Saat Pasang Menuju Surut 


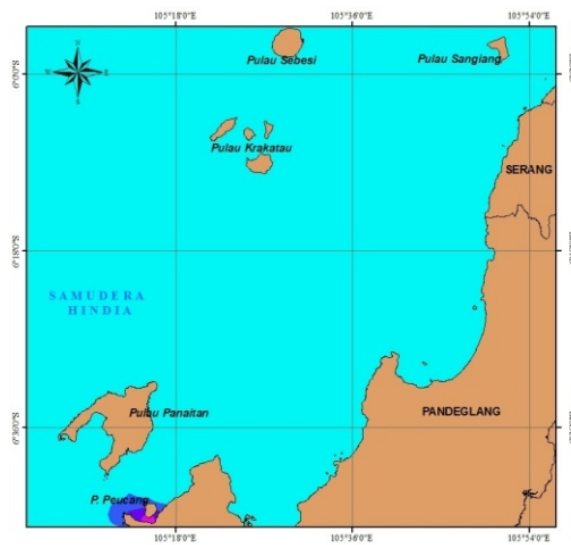

c. Saat Surut Terendah

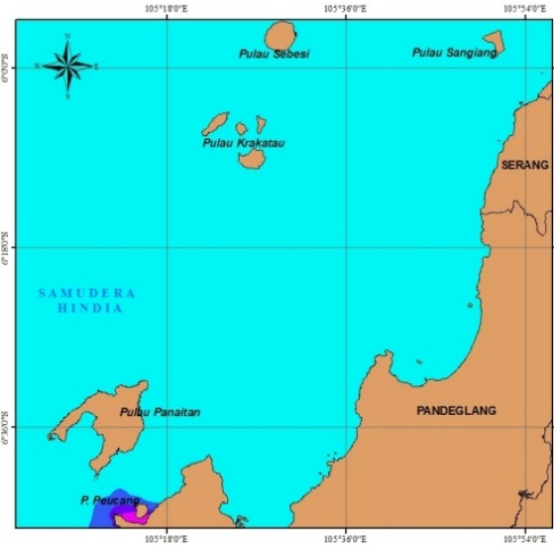

d. Saat Surut Menuju Pasang

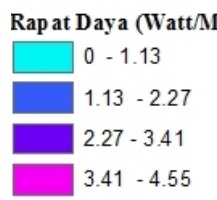

Gambar 6. Pola Arus di Perairan Selat Sunda (a. Pasang Tertinggi, b. Pasang Menuju Surut, c. Surut Terendah, d. Surut Menuju Pasang)

\section{Validasi Arus}

Pola arus yang dihasilkan dari simulasi model yang terjadi di Perairan Selat Sunda dengan menggunakan software DHI MIKE 21, memiliki nilai kecepatan dan arah sehingga perlu dilakukan verifikasi data. Verifikasi data merupakan hasil perbandingan data arus yang diukur di lapangan dengan data hasil simulasi model. Verifikasi data dilakukan dengan tujuan untuk mengetahui apakah hasil simulasi dari model mendekati keadaan yang terjadi di lapangan.

Verifikasi data yang dilakukan dengan membandingkan kecepatan dan arah arus dalam masing-masing komponennya, menghasilkan nilai CF sebesar 1,12 untuk data komponen arus u termasuk kategori baik, dan 1,07 untuk data komponen $\mathrm{v}$ termasuk kategori baik.

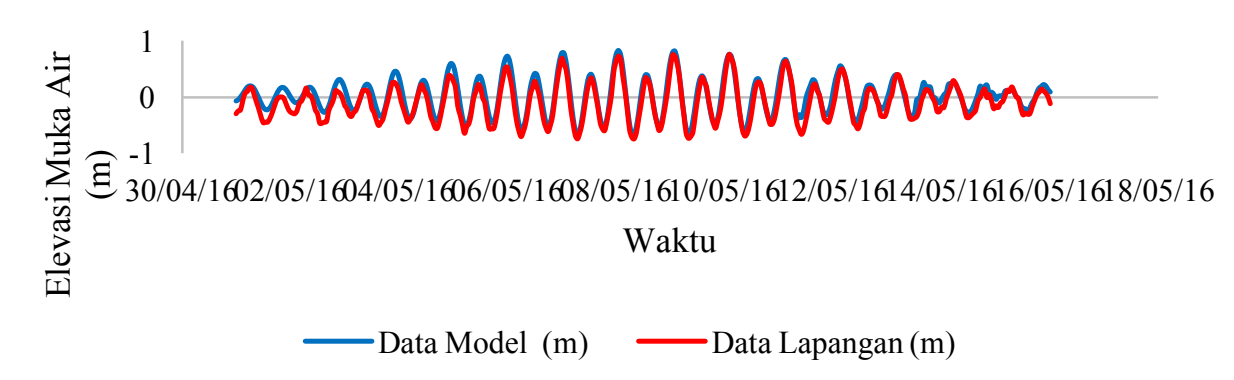

Gambar 7. Grafik Perbandingan Data Pasang Surut Hasil Model dan Lapangan

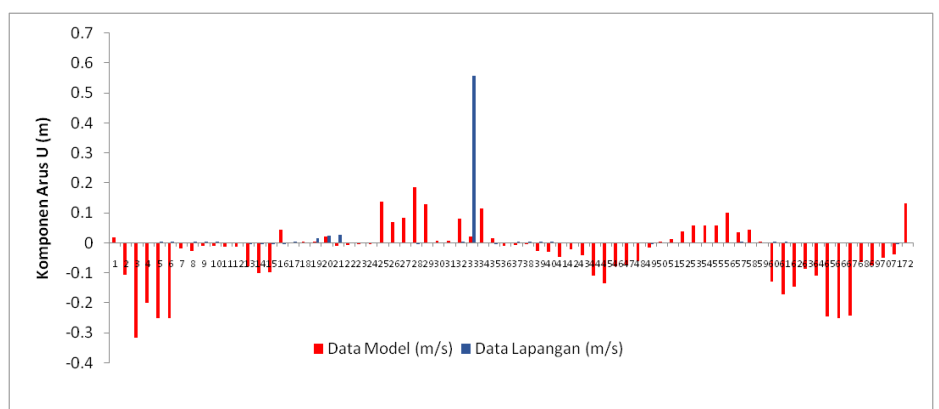

Gambar 8. Grafik Perbandingan Komponen Arus u Hasil Model dan Komponen Arus u Lapangan 


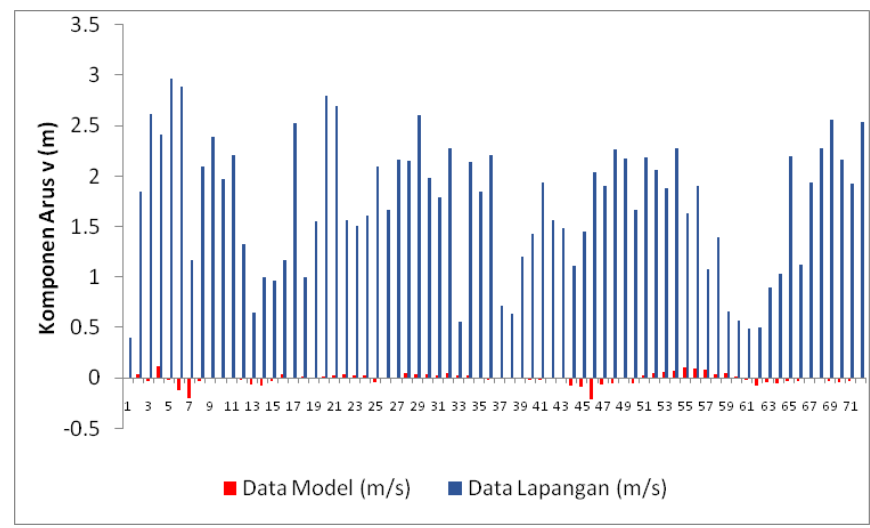

Gambar 9. Grafik Perbandingan Komponen Arus v Hasil Model dan Komponen Arus v Lapangan

\section{KESIMPULAN}

Pola dan karakteristik arus di Selat Sunda berdasarkan pengukuran bergerak dominan bergerak ke selatan dan barat daya. Sedangkan berdasarkan simulasi numerik dapat diketahui bahwa, saat pasang tertinggi dan saat surut menuju pasang arusnya bergerak ke arah barat daya atau ke arah Samudera Hindia. Sedangkan pada saat surut terendah dan saat pasang menuju surut arah arus bergerak menuju ke arah pantai Pandeglang dan Laut Jawa. Nilai kecepatan terendah sebesar 0,00024 m/s pada saat kondisi surut terendah dan kecepatan tertinggi sebesar $0,8765 \mathrm{~m} / \mathrm{s}$ pada saat kondisi pasang menuju surut.

Konversi nilai rapat daya tertinggi pada saat pasang sebesar $3.90 \mathrm{~W} / \mathrm{m}^{2}$ dan pada saat surut sebesar $3.54 \mathrm{~W} / \mathrm{m}^{2}$. Saat pasang menuju surut nilai rapat daya sebesar $4.49 \mathrm{~W} / \mathrm{m}^{2}$ dan pada saat surut menuju pasang nilai rapat daya sebesar $4.51 \mathrm{~W} / \mathrm{m}^{2}$. Daerah paling berpotensi dalam pemanfaatan energi arus laut sebagai pembangkit listrik terdapat di perairan sekitar Ujung Kulon dan Pulau Peucang (Tanjung Jungkulan dan Ma Cikuya) dengan nilai rapat daya tertinggi sebesar $4.51 \mathrm{~W} / \mathrm{m}^{2}$ yang dihasilkan pada saat kondisi surut menuju pasang.

\section{Ucapan Terima Kasih}

Terima Kasih kepada keluarga besar KRI Rigel-933, Dinas Hidro Oseanografi TNI Angkatan Laut yang telah mengizinkan penulis bergabung dalam kegiatan survey.

\section{DAFTAR PUSTAKA}

Fraenkel, P.L. 2001. Power from Marine Currents. Proceedings of The Institution of Mechanical Engineers. Journal of Power and Energy., 216(A1): 1-14.

Hadi, S. dan I.M. Radjawane. 2009. Arus Laut. Institut Teknologi Bandung, Bandung.

Hagermen, G. 2006. EPRI North American Tidal in Stream Power Feasibility Demonstration Project:

Methodology for Estimating Tidal Current Energy Resource and Power Production by Tidal

Stream Energy Conversion (TISEC) Device. EPRI. America

Kementerian Energi Dan Sumberdaya Mineral. 2012. Kajian Indonesia Energy Outlook. $95 \mathrm{hlm}$.

Moreno, N., R. Sallent, A. Espi, D. Bao, and Y. Teillet. 2008. Ocean Current's Energy: How to Produce Electrical Energy Thanks to The Marine Currents?. University of Gavle, Gavle, 23 p.

Pariwono, J.I. 1999. Kondisi Oseanografi Perairan Pesisir Lampung. Proyek Pesisir Publication, Technical Report (TE-99/12-I) Coastal Resource Center, University of Rhode Island, Jakarta, $28 \mathrm{hlm}$.

Poerbandono dan Djunarsih. 2005. Survei Hidrografi. Refika Aditama, Bandung.

Sugiyono. 2009. Metode Penelitian Kuantitatif, Kualitatif, dan R\&D. Alfabeta, Bandung.

Teledyne Technology Company. 2016. Teledyne RD Instruments Profiling Ocean Currents from Moving Ship. http://www.adcp.com (28 Agustus 2016) 